Annual precipitation during the study

\title{
Simulated Grazing Manage- ment Systems in Relation to Shrub Growth Responses
}

\section{E. EARL WILLARD AND CYRUS M. MCKELL}

Highlight: Little rabbitbrush and snowberry plants were clipped for 5 years to simulate annual browsing at the same time each year, under deferred-rotation, alternate-rest, and rest-rotation grazing systems at each of three different intensitics $(30,60$, and $90 \%$ of herbage removal). The number of new sprouts was increased by some clipping treatments and all intensities of clipping in both species. Sprout length was reduced by all clipping schedules and intensities of clipping on little rabbitbrush but not on snowberry. Mortality of sprouts was high during their first year of growth. Carbohydrate reserves were lowered for both species by some clipping schedules and by all intensities of clipping.

This investigation was undertaken to determine the effects of intensity and time of clipping on the carbohydrate reserves and sprouting responses of two wildland shrubs. Little rabbitbrush (Chrysothamnus viscidiflorus (Hook.) Nutt.) and snowberry (Symphoricarpos vaccinioides Rydb.) were selected as representatives of the sprouting shrubs that are important browse plants for livestock and wild ungulates.

Past research on shrub sprouting has been restricted mostly to the effects of burning, chemicals, and mowing or cutting. In such studies all of the top growth was removed to determine the effect of time of cutting and the resultant carbohydrate reserve levels on sprouting responses. We used clipping to determine how browsing might be used to manipulate sprouting.

Several researchers have reported a positive correlation between carbohydrate reserve levels in roots of woody plants and the degree of sprouting (Baker, 1918; Aldous, 1935; Zehngraff, 1949; Jones and Laude, 1960; Tew, 1970). Yocum (1945) reported that bud growth depended on food reserves. However, Wright and Stinson (1970) showed that the regrowth following cutting was not in direct proportion to the total carbo-

At the time the article was written, the authors were research assistant and professor of range ecology, Range Science Department, Utah State University, Logan. Willard is now a postdoctoral fellow, Ford Foundation, Universidad Nacional del Sur, Bahía Blanca, Argentina.

Manuscript received July 6, 1972. hydrate reserves in the roots of mesquite (Prosopis glandulosa var. glandulosa). They believed that factors other than root reserves limited regrowth after a certain level of carbohydrates was restored.

Donart (1968) and Donart and Cook (1970) reported on the carbohydrate reserve cycle in snowberry and little rabbitbrush following clipping. Plants clipped when carbohydrates were at the low point in the spring had root reserves below those of control plants. Later, the reserves increased in clipped plants and were higher than in the controls. Intense clipping when carbohydrates were high reduced root reserves, which condition persisted through the growing season.

McKell (1956) reported sprouting of little rabbitbrush plants on which top growth had been limited by an extreme drought. Sprouts 4-6 inches long were also observed where the tops had been chopped off to clear research plots. Root sprouting of little rabbitbrush is common following firc (Stoddard and Smith, effective in influencing sprouting of snowberry (Aldous, 1929). Thus, it is clear from the literature that complete top removal of these two species influences sprouting.

\section{Methods}

The study area was in a mountainous of northern Utah. The plots were at an elevation of approximately $2,080 \mathrm{~m}$ on slopes facing the south and southwest. 1955). Mowing has been found to be summer range in the Wasatch Mountains ranged from 63 to $81 \mathrm{~cm}$, mostly in the form of snow. Snow often accumulates to depths of $1-2 \mathrm{~m}$ on the slopes, and the spring melt brings the soil moisture content to field capacity. Rainfall is normally high in the spring and low in July, August, and the first part of September. Plants complete their growth cycles by mid-summer or else exhibit reduced growth rates. Several shrub species in the area renew growth for short periods when precipitation increases in the fall.

The soils average $75 \mathrm{~cm}$ in depth and consist of $\mathrm{A}, \mathrm{B}$, and $\mathrm{B}_{2}$ horizons. Textures range from silt loam at the surface to a clay layer at around $75 \mathrm{~cm}$, which blends into rocky subsoil.

Shrubs were clipped to simulate annual browsing at the same time each year, under deferred-rotation, alternate-rest, and rest-rotation grazing systems at each of three different intensities $(30,60$ and $90 \%$ of foliage removal). Control plants were left unclipped. Clipping dates were established to represent early (June 1), mid (July 15), and late (September 1) season browsing. Clipping schedules were as follows:

1) No clipping

2) Clipped annually on June 1

3) Clipped annually on July 15

4) Clipped annually on September 1

5) Deferred-rotation, clipped annually, with a rotation of dates

6) Alternate-rest, clipped every other year on June 1

7) Alternate-rest, clipped every other year on July 15

8) Rest-rotation, clipped once each year at different seasons for two consecutive years and rested the third year.

Clipping treatments were applied for 5 years (1965-1969). Five plants of each species were selected for defoliation at each intensity for each of the seven schedules. This basic design was duplicated in order to have a complete series of plants for excavation in the spring for carbohydrate and sprout measurements and again in the fall for sprout measurements.

Plants were clipped to simulate grazing by livestock, particularly sheep (DeBano, 1957; Fears, 1966) and wild ungulates. The percent removed was estimated ocularly. A similar technique was used by Child (1970) for desert shrubs in western Utah.

Root samples for carbohydrate analysis were collected in the spring of 1970 at the time when carbohydrate depletion was judged to be greatest. Plants were dug to obtain as much of the root system as possible. The soil was then carefully washed from the roots and crowns. Roots were divided into three groups: roots 6 $\mathrm{mm}$ or less in diameter, roots greater than 
$6 \mathrm{~mm}$ in diameter, and root crowns. The root crown consisted of that tissue between the first root and the first branch. Samples were stored in $95 \%$ ethanol for future drying and grinding.

The number and length of sprouts were quantified in 1970 , when plants were excavated in the spring, and again in the fall on another series of plants after growth had essentially ceased. The difference between the number of sprouts in the spring and in the fall represented mortality.

Root and crown samples were analyzed for total available carbohydrates, using laboratory techniques described by Trlica and Cook (1971). Weinmann (1946) and Smith et al. (1964) have defined total available carbohydrates (TAC) as the reducing and non-reducing sugars, starches, dextrins, and fructosans. Results are reported as milligrams of TAC per gram of dry material.

\section{Results and Discussion}

\section{Sprouting Responses}

\section{Little rabbitbrush}

With the exception of plants clipped annually on June 1 , the average number of new sprouts per plant in the spring of 1970 was greater for clipped than for unclipped plants (Fig. 1). Plants clipped by the rest-rotation schedule and June 1 alternate-rest schedule also had more sprouts than plants clipped annually on June 1. By fall, the number of live sprouts had decreased in all clipped plants and in a lesser degree in non-clipped plants. Plants receiving the July 15 alternate-rest treatment had more sprouts than all systems except the deferredrotation and rest-rotation treatments. The control and July 15 alternate-rest treatment plants had the least sprout mor- tality from spring to fall.

Sprout numbers in the spring were significantly greater for plants that had been clipped than for the control plants (Fig. 2). Plants clipped at the $30 \%$ intensity had more sprouts than those of the $60 \%$ treatment, but not more than the $90 \%$ treatment. Sprout mortality through the growing season reduced sprout numbers, so that the intensity of clipping had no effect on number of sprouts in the fall.

Spring sprout length was reduced by all clipping intensities (Fig. 2). Plants receiving $30 \%$ defoliation had significantly longer sprouts than those in the $60 \%$ treatment, but they were similar in length to the $90 \%$ treatment. By fall, the control plants and those clipped $60 \%$ had longer sprouts than those clipped $90 \%$. Plants clipped 30 and $60 \%$ had essentially the same sprout lengths as non-clipped plants by the end of summer.

Elongation of new sprouts of little rabbitbrush in the spring was significantly less on plants clipped by various schedules than for unclipped ones (Fig. 1). Plants clipped annually on June 1, July 15 , or September 1 , or by the June 1 alternate-rest treatment had shorter sprouts than had plants on the other clipping schedules. Most clipping schedules allowed recovery of sprout vigor during the growing season. Only those plants clipped annually on June 1 or July 15 had shorter sprouts than unclipped plants had in the fall.

\section{Snowberry}

Plants clipped by the deferred-rotation and July 15 alternate-rest clipping schedules had more new sprouts in the spring than controls (Fig. 3). No other dif- ferences were observed. By fall, the number of sprouts had declined for all clipping treatments, but was essentially the same for control plants. Only those plants receiving the July 15 alternate rest clipping schedule had more sprouts in September than the controls. Control plants and those of the July 15 alternaterest treatment had the smallest percent of sprout mortality from spring to fall.

Sprout numbers in the spring were increased by all intensities of clipping. The lowest numbers were in controls; the highest were in plants clipped $90 \%$. The 30 and $60 \%$ treatments had an intermediate number of sprouts but were not different from each other (Fig. 2). Plants clipped $60 \%$ had more sprouts than controls of those clipped $30 \%$. Sprout mortality was substantial in all plants, ranging from $38 \%$ on plants clipped $60 \%$ to $64 \%$ for plants clipped $90 \%$.

No differences in sprout length in the spring or fall were found in snowberry plants clipped under any clipping schedules or intensities used in this investigation (Figs. 2 and 3).

\section{Sprout development}

The high degree of sprout mortality on these species indicates that the shrubs produce more initial sprouts than can be supported. Activated buds on the root crown of a shrub are dependent on the storcd carbohydrates for initial elongation and leaf development. Limited TAC reserves available to these young sprouts may result in only the more competitive or favorably-located sprouts being able to develop to a point of being self-sufficient. Those sprouts which have not attained self-sufficiency by the time of maximum TAC depletion in the spring probably die
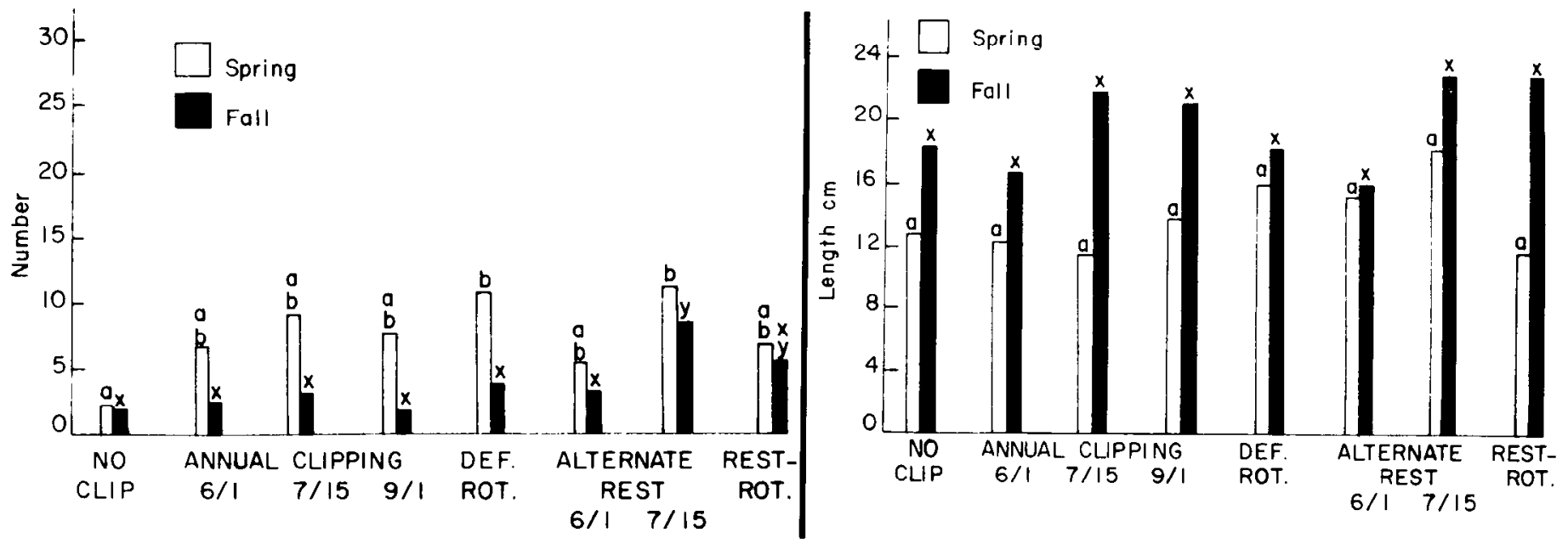

Fig. 1. A verage number (left) and length (right) of little rabbitbrush sprouts in the spring and fall following 5 years of clipping. (Bars labeled with the same letter are not significantly different at the .05 level.) 

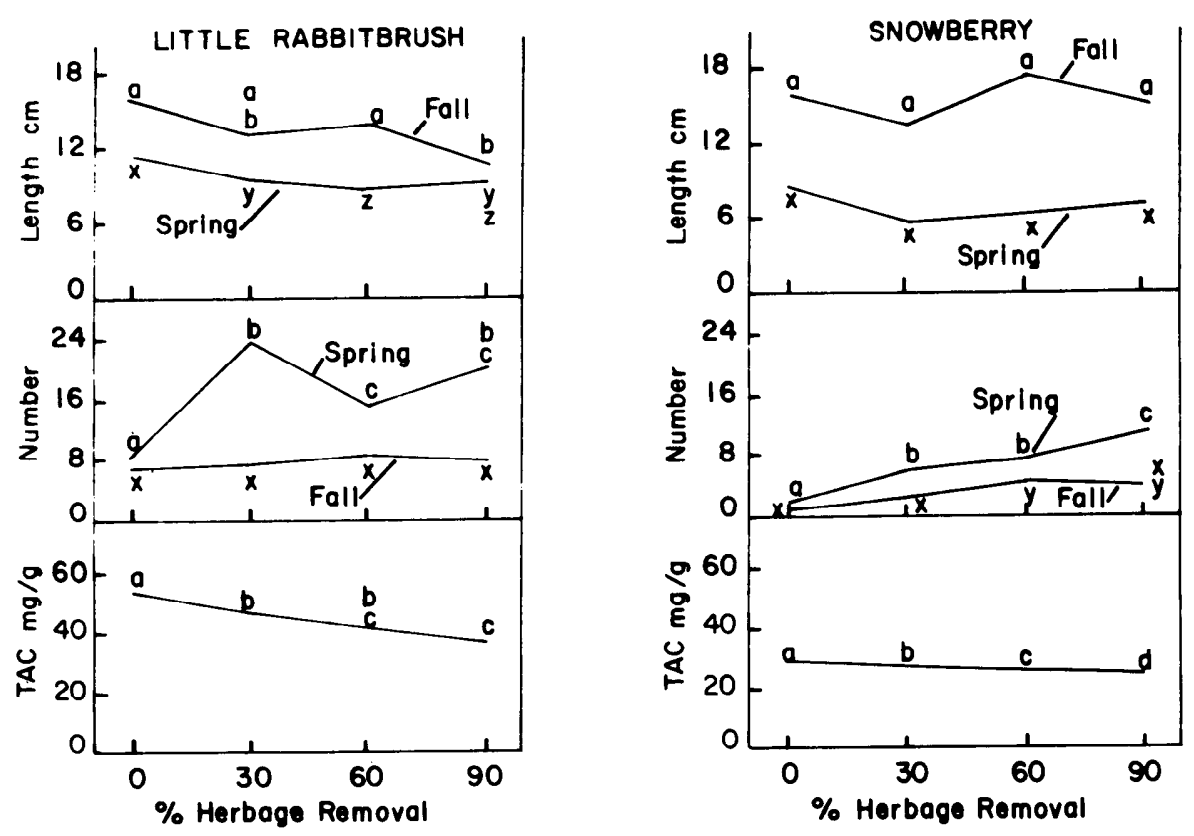

Fig. 2. Total available carbohydrates (TAC), average number, and average length of new sprouts of little rabbitbrush and snowberry following 5 years of clipping at different intensities. (Points on curves labeled with the same letter are not significantly different at the .05 level.)

soon afterward.

Sprouts were observed to be in various stages of development on June 1 when the shrubs were excavated. Some little rabbitbrush sprouts were dead at the tips, and others were wilted. Since they were initiated at or slightly above the soil surface, etiolation could not be considered operative.

Many snowberry sprouts had not elongated sufficiently by June 1 to reach the soil surface. Some of those still in the mineral soil and others extending into the litter and above the soil surface had begun dying at the tips. Etiolation was much more apparent in some plants than in others.

Snowberry plants produced from one to a few water sprouts, with little regard to the treatments applied. These sprouts were much longer than the associated sprouts and apparently masked the general effect of clipping on average sprout length.

\section{Carbohydrate Reserves}

Small roots of littlc rabbitbrush and root crowns of snowberry were found to be the most important and active locations for carbohydrate reserves. These tissues contained the greatest amount of stored carbohydrates and were more responsive to clipping treatments than those of the other storage tissues analyzed. Therefore, these tissues are implied when referring to $\mathrm{TAC}$ reserves.

\section{Little rabbitbrush}

There was no difference in TAC among clipped plants at the time of spring depletion. However, plants clipped annually on June 1 and July 15 , alternate years on July 15, and by the deferred rotation schedule had less TAC than non-clipped plants (Fig. 4).

All three intensities of defoliation reduced TAC reserves (Fig. 2). Plants clipped at $90 \%$ intensity had less TAC than plants clipped $30 \%$.

\section{Snowberry}

Total available carbohydrates were significantly less in plants clipped annually on July 15 than in those clipped annually on September 1, alternatc ycars on July 15 , or unclipped plants. No other differences were detected (Fig. 4).

Plants clipped at any intensity had lower TAC reserves than unclipped plants. Reserves decreased as the intensity of defoliation increased (Fig. 2).

\section{Carbohydrate replenishment}

Reserves which are depleted during the initiation of spring growth in both species are replenished rapidly in June (Baker, 1967). Soil moisture is adequate for rapid growth during the spring due to spring snow melt and high spring rainfall (Willard, 1972). Thus, plants clipped on June 1 had about a month of adequate soil moisture for rapid growth and TAC storage.

Little rabbitbrush plants clipped annually on June 1 were not fully able to replenish reserves used for regrowth. However, rest for one complete year following June 1 clipping was sufficient to allow full recovery. The degree of TAC depletion following clipping was much less in snowberry than in little rabbitbrush (Fig. 4). The favorable spring grow-
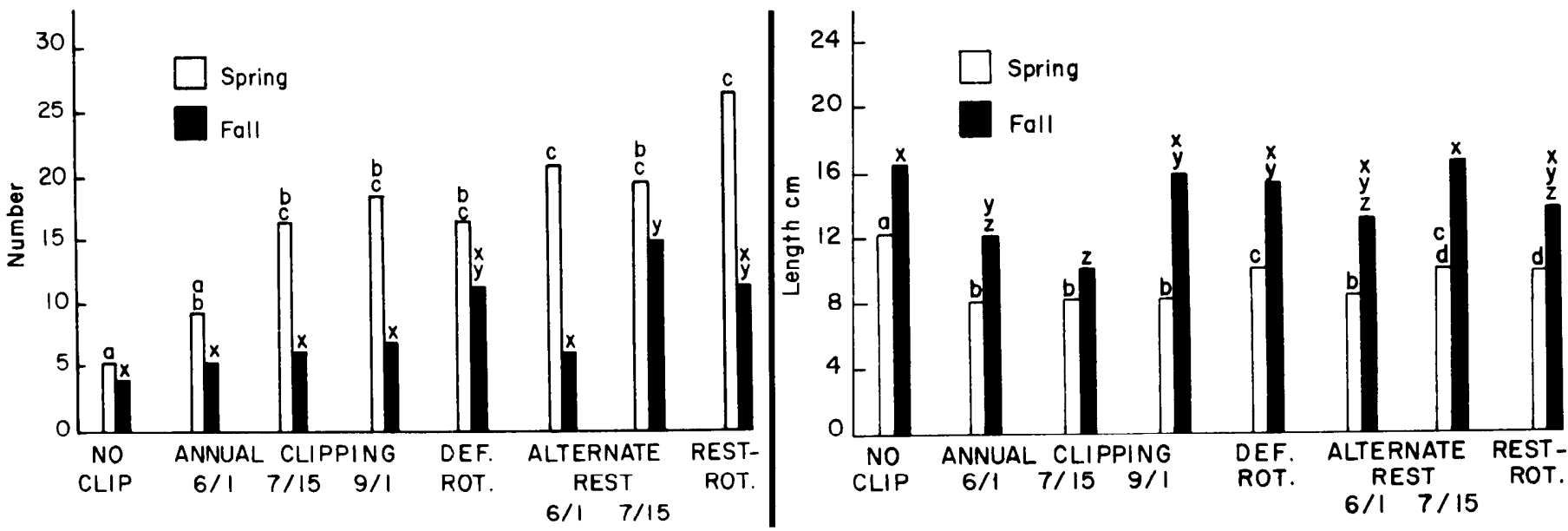

Fig. 3. Average number (left) and length (right) of snowberry sprouts in the spring and fall following 5 years of clipping. (Bars labeled with the same letter are not significantly different at the .05 level.) 

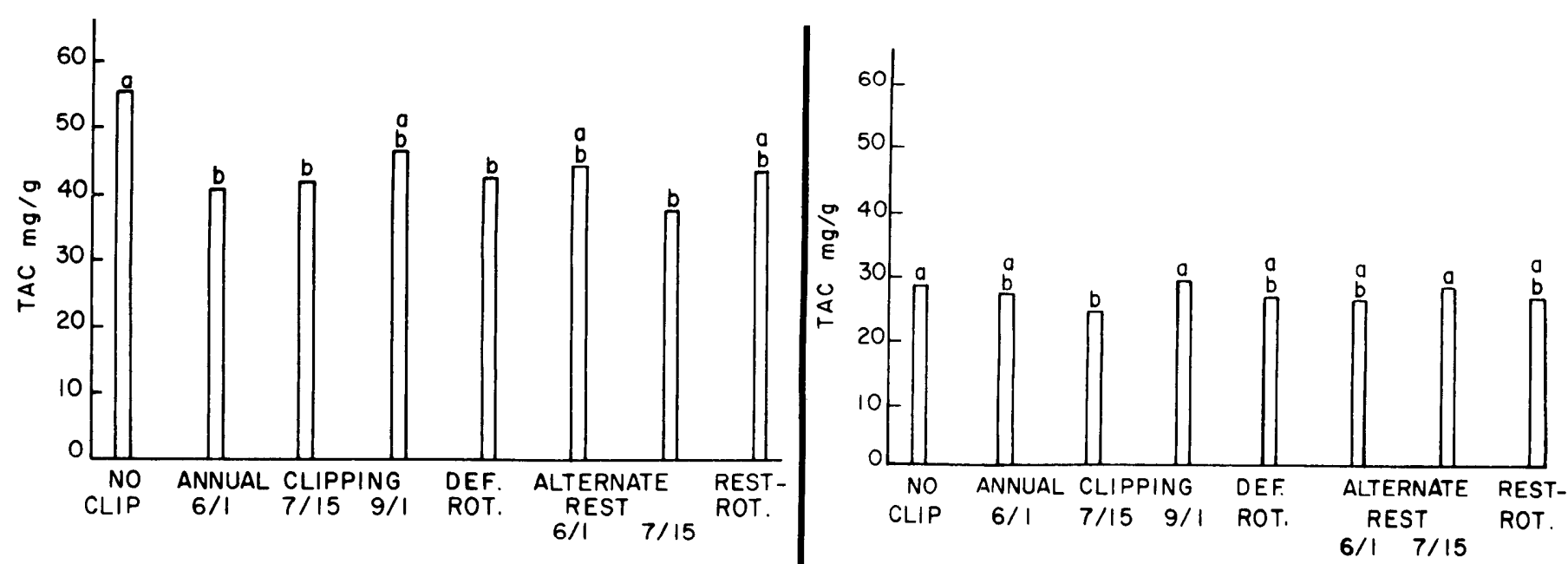

Fig. 4. Average total available carbohydrates (TAC) in small roots of little rabbitbrush (left) and root crowns of snowberry (right) in the spring following 5 years of different clipping schedules. (Bars labeled with the same letter are not significantly different at the .05 level.)

ing conditions were adequate to allow snowberry to fully replenish TAC reserves following June 1 clipping.

The July 15 clipping occurred at a time of reduced soil moisture. The spring flush of growth lowered the soil moisture content, and July and August had less rainfall than the other months of the growing season (Willard, 1972). Therefore, plants of both species were unable to make adequate growth to fully replace TAC reserves when clipped annually on July 15 . One full year of rest following July 15 clipping was sufficient for snowberry to replace TAC reserves to a level of unclipped plants, but insufficient for little rabbitbrush.

September carbohydrate reserve levels of unclipped plants of these species are at or near maximum for the year (Baker, 1967). Increased rainfall in September provides more suitable growing conditions than are present in July and August. These factors help explain why plants of both species clipped on September 1 were able to fully replenish TAC reserves to a level of unclipped plants.

\section{Grazing Management Implications}

Certain precautions should be observed in developing a grazing schedule for these shrubs. Annual grazing in June or July may be harmful to the plants through a reduction of TAC reserves. Browsing to favor these shrubs should be planned for late summer or early fall if the grazing season is the same every year. Otherwise, schedules should include periodic deferment from browsing in June and July. Such a grazing scheme would also allow important associated forage species such as Agropyron inerme, Stipa lettermanii, Lupinus laxiflorus, and
Geranium fremontii the opportunity to recover from initial spring TAC depletion and complete most of their annual growth. These associated grasses and forbs were observed to complete most of their growth by the first of September so late grazing should help maintain the stands of these important forage species.

Little rabbitbrush plants should be browsed lightly in July, August, or September to increase sprouting the following spring. Browsing in July on alternate years would result in the maximum number of live sprouts in the fall.

Heavy browsing of snowberry in August or September should result in the initiation of a maximum number of sprouts. However, browsing in July on alternate years would result in the maxinum number of live sprouts in the fall.

Heavy browsing of snowberry in August or September should result in the initiation of a maximum number of sprouts. However, browsing in July on alternate years may allow a maximum number of sprouts to survive to the end of the growing season. The validity of these recommendations should be further tested with actual grazing trials.

\section{Literature Cited}

Aldous, A. E. 1929. The eradication of brush and weeds from pasture lands. J. Amer. Soc. Agron. 21:660-666.

Aldous, A. E. 1935. Management of Kansas permanent pastures. Kansas Agr. Exp. Sta. Bull. 272.44 p.

Baker, F. S. 1918. Aspen reproduction in relation to management. J. Forest. 16:389-398.

Baker, R. C. 1967. The effect of season and intensity of herbage removal on the physical and chemical responses of some range plants. MS Thesis, Utah State Univ., Logan. Child, R. D. 1970. Recovery of desert range plants in various states of vigor during a seven year period of non-use. MS Thesis, Utah State Univ., Logan.

DeBano, L. G. 1957. The effect of season and degree of use on the physiological response and nutritive content of desert forage plants. MS Thesis, Utah State Univ., Logan.

Donart, G. B. 1968. Carbohydrate reserves in mountain range plants with respect to phenological stage of development and artificial defoliation. Ph. D. Dissertation, Utah State Univ., Logan.

Donart, G. B., and C. W. Cook. 1970. Carbohydrate reserve content of mountain range plants following defoliation and regrowth. J. Range Manage. 23:15-19.

Fears, R. D. 1966. The effect of intensity and season of use on recovery of desert range plants. MS Thesis, Utah State Univ., Logan.

Jones, M. B., and H. M. Laude. 1960. Relationships between sprouting in chamise and the physiological condition of the plant. J. Range Manage. 13:210-214.

McKell, C. M. 1956. Some characteristics contributing to the establishment of rabbitbrush (Chrysothamnus spp.). Ph. D. Dissertation, Oregon State Univ., Corvallis.

Smith, D., G. M. Paulsen, and C. A. Raguse. 1964. Extraction of total available carbohydrates from grass and legume tissues. Plant Physiol. 39:960-962.

Stoddart, L. A., and A. D. Smith. 1955. Range management. 2nd ed. McGraw-Hill, New York. 433 p.

Tew, R. K. 1970. Root carbohydrate reserves in vegetative reproduction of aspen. Forest Sci. 16:318-320.

Trlica, M. J., and C. W. Cook. 1971. Defoliation effects on carbohydrate reserves of desert species. J. Range Manage. 24:418-425.

Weinmann, H. 1946. Some fundamental aspects of modern pasture management. Rhod. Agr. J. 43:418-425.

Willard, E. E. 1972. Some factors involved in activation of sprouting in little rabbitbrush and snowberry on summer range. $\mathrm{Ph}$. $\mathrm{D}$. Dissertation, Utah State Univ., Logan.

Wright, H. A., and K. J. Stinson. 1970. Response of mesquite to season of top removal. J. Range Manage. 23:127-128. 